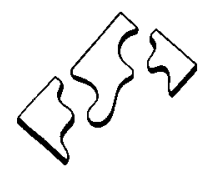

\title{
Learning to Live in the Home of Language: Hearing the Pedagogic Voice as Poetic ${ }^{1}$
}

\section{David G. Smith}

St. Thomas University

To reflect on language means to reach the speaking of language in such a way that this speaking takes place as that which grants an abode for the being of mortals.

\section{Heidegger}

To learn to speak in a way that grants an abode for the being of mortals; such is our task here. And by mortals, we mean ourselves, our children and school people, which includes us all. An abode is a place where one lives, and means, from its Anglo-Saxon original, a place where one can go on being. When we speak, therefore, of speaking as reaching an abode, a home, a place to go on living, we see at once that without a true speaking, without language as a home, we cannot be at home at all, nor go on living.

Recently, a teacher said that, more and more, school authorities are having trouble sending children home. That is, at three o'clock, more and more children feel that that house at 12th and Pine is not their home, not a place where they can go on being. So they stay at school longer, not to do anything in particular-certainly not to do school work -but because, perhaps, it is warm on a cold day, or it is bright on a dark day, or because a particular teacher is there planning lessons for tomorrow, or a janitor is whistling while he works. In other words, in more and more places of domicile today, there is not a true speaking, not a granting of an abode, not an intimacy which can let a child be. To say there is not a true speaking in a place of domicile is a tragedy for a child, for to be an infant means, in the first place, literally, to be speechless. So, to be born speechless in a place where there is no true speaking means a real impoverishment.

What language will a child learn from parents who cannot speak with one another? Will he learn the language of one parent and not the other, depending on which parent wins his favor? Will he be led to believe that there are two languages in any family, and that the choice of language involves a political decision, a playing off of parental powers? Or will such a child simply refuse to choose and, hence, remain speechless, locked into a virtual silence?

Such is the condition we seem to have come to in our time, where language is thought of in terms of power, in terms of being a "tool of communication," a weapon for personal or collective use. Even to speak of language ability as "communication skill" is a travesty, if by skill is meant a mastery over conventions necessary to get one's way. For while such a mastery may indeed reap a personal or collective benefit, it does not guarantee an abode, a place to go on living. Effective speaking does not mean skilled ability in, say, "getting one's point across," but rather an ability to grant an abode for the being of mortals. 
How often it is we hear ourselves, our students, our colleagues, say "What I'm trying to say is . .." And in our "trying," we put things "in other words ...," or give examples, or speak through illustrations-all as stumbling efforts to say what it is we are trying to say. Communications experts might tell us we need to take a language course to build up our vocabulary so that we can really say what we want to say. And such efforts may indeed be helpful. People with a gift for words do have a certain aura, a certain engaging mystery. It is as if they are able to say that which we all know and want to say but cannot. People with a gift for words, poets, artists, men of letters, in their saying are able to gather us up with themselves by being able to bring into speech that which we of ourselves know, but cannot say. So that when a true poet speaks, for example, the burden of our own speechlessness is lifted for a while, and we are able to go on being. People with a gift for words grant an abode for the being of mortals.

But who grants an abode for the poet or for those who seem able to speak and thus provide a place for us? Here we must insist that it is language itself which speaks through them and provides them with a home. It is language, not as tool, or weapon, or stylistic artifice, but as that which calls them ever and ever again to keep on "trying to say." Poets, people with a gift for words, stand in the middle of things, in that "between" which lies between us as mortals and the voice of language itself, the logos, which they try to speak. Heidegger would say the poet stands between the gods and men.

So here I am, in the middle way ...

Trying to learn to use words, and every attempt

Is a wholly new start, and a different kind of failure

Because one has only learnt to get the better of words

For the thing one no longer has to say ... And so each venture

Is a new beginning...

There is only the fight to recover what has been lost

And found and lost again and again: and now, under conditions

That seem unpropitious. But perhaps neither gain nor loss.

For us, there is only the trying. The rest is not our business.

So says T. S. Eliot in the Four Quartets. The poet then, the one of the logos, learns that trying to "use" words leads to failure because getting the better of words only means to learn the thing one no longer has to say.

Does this mean that words are useless and that we should give up our attempts? On the contrary, for every attempt is a "fight to recover what 
has been lost, and found, and lost again and again." The question of "gain or loss" is beside the matter. "For us, there is only the trying. The rest is not our business."

Only the trying, the rest is not our business. Only the longing and the struggle to recover what has been lost and found and lost again and again. To be attentive to the voice of language is not simply to learn new words but to learn a "different kind of failure." Not a failure in the conventional sense of failing to achieve one's goals and objectives, but a failure which is at the same time a "venture," a "wholly new start," a form of recovery of that which has been lost, which, in the recovery, becomes lost again and again. Cost efficiency, accountability, profitability-all these have little to do with a true speaking. They are "not our business." Our business is "the trying," because only in the trying is a recovery possible, a recovery which is at the same time a form of losing, a sense of loss which impels us to our true business. Such way of being in the midst of language is the "wisdom of humility" says Eliot later in the poem. And "humility is endless."

When one listens to parents and teachers speak of living with the children in their midst, the most striking feature of all is how the speaking is indeed endless. Many teachers, however, are in a special "bind" because their daily dealings are formally charged with the language of objectives, ends, and goals. But such language has very little to do with the realities of living with children. So, many teachers are reduced to living a sort of schizophrenic compromise, whereby they dutifully discharge their formal responsibilities in conversations with district curriculum supervisors and government accountability experts, but when that is done, they go back to, they recover, that momentarily lost form of life which enables them to be with children in a more liveable way. The saddest teachers of all are those who never learn the real difference between formal curricular goals and the only goal of any importance: namely, learning to live together in the house of being, which is language itself, the abode where mortals may dwell.

How is the language of living together with our children endless? One hears the endlessness of it when, as researcher or interested person, one tries to put an end to it. When, after an interview with a parent or a teacher, one turns the tape recorder off and puts down one's notebook with a certain satisfaction that the conversation has spent itself and that all parties have had their say, there, in the momentary "silence" of rising for another cup of coffee, or in the silence of exchanging pleasantries, there again and again, one hears and knows that the story has not been and never will be completely told. Because in the silence when conversation ceases, one hears again a child crying in the bedroom next door, or one hears a tentative knock on the staffroom door with a call for assistance. But not only this: In the silence when conversation ceases, one hears within, in the inner ear, that the tape recording, that technical instrument of language, with its claims to giving an absolutely faithful reproduction of human speech, has somehow done a violence to our speaking. Because the moment the tape is switched off, with the conversation recorded "faithfully," one thinks immediately of how things 
should have been, or could have been said differently-of how, really, not all the intricacies of one's involvements have been covered, or uncovered, and that there is so much still to be said. For us there is only the trying. The rest is not our business. So the poet said.

It is in the nature of our human speaking, then, that neither can it be faithfully reproduced, nor can it be silenced. The words on a tape, or in a notebook, do not faithfully represent human language because it is language itself, as the primordial logos, which makes possible in the first place the movement of our lips and the quivers in the magnetic box. Our language is our being, as Heidegger has always reminded us. We dwell in it; it is the place of our mortal abode. True human speaking is always original, non-reproducible, and never finished. We never finally arrive at the place which forever impels us to speak, just as we cannot finally, definitively speak of that which impels us, our starting point.

Where is our beginning? When was Johnny Kilshaw born? When did his reading problems begin? How old was he when he began to read? When we try to answer these questions in any way which goes beyond a simple and empty chronology, perhaps simplified and emptied for administrative efficiency, we see how enormously difficult it is to provide an answer. It is something like trying to answer the question, "When did the Cold War begin?" Did it begin with Churchill's remarks about an Iron Curtain? Or at Yalta with Roosevelt's compromise; or with Stalin's scourge, or with Lenin, or Marx, or the rise of British Industrialism, or with the Enlightenment, or Descartes, or with Galileo and the new science, or with medieval scholasticism, or the early church, or with Aristotle, Plato, or the Pre-Socratics, or with the Barbarian hordes, or with Abraham, or Adam? Who can answer the question in any way that would satisfy us once and for all? But at the same time, even though we cannot place its origins precisely, we know we are in the very midst of such a war. And in wanting to understand it, we search for its roots. Yet the more we search, the more we search. And it is the searching, the trying, the attempting, which keeps our speaking about it alive, the death of which may result in the annihilation of speech altogether. So our hope lies not so much in finding a definitive answer to the question of origin, but in continually recovering it as a question, which means recovering the wonder which makes our speaking in the present possible and which allows that speaking and that living to go on.

What about the origin of Johnny's learning difficulties? When teachers talk about such things over coffee, usually the talk reduces to a consensus that Johnny's troubles are rooted in a "poor home situation" or a "broken home." The diagnosis is easy enough to make, yet it also speaks of the way in which our language about children has taken the form of a terrifying sociological determinism. For the truth is that the rationalization is really of little help at all either to Johnny or indeed to the question of how to live in the true home of language. Because, no matter how one might care to "explain" Johnny's difficulties, the brute fact remains that Johnny is still "there," or "here," hanging around the school after closing, or forever interrupting the flow of formally planned events in the classroom. 
And what are those interminable interruptions but a deep questioning of the origins of classroom life; an invitation to us as educators to interminably recover the question of our purposes. But more than that, those interruptions come as a question as to whether the formal speaking of educators is really a speaking at all if it cannot embrace within itself those with whom it dwells. If the formal language of educators cannot grant an abode for the being of mortal children, something is wrong with our understanding of language. There was a day when the interruption of children into the language of the school was slight, understandable as a minor aberration from a reasonably decent state of affairs. But now we hear more and more educators speak of those interruptions as Interruption. Many seasoned teachers say they can no longer teach the way they used to. We might put it another way and say that the former formal language of schooling is in a state of collapse, in the sense that, in its basic instrumentalism, it can no longer speak to, for, or with mortals in its midst.

After all, what is this "broken home," that catch-all term used to describe the situation of so many children today-if it is not also a place living out the collapse of language, the death of true speaking, and thus at the same time, in the same breath, a morgue for the living dead. As educators we must not take unquestioningly a term like "broken home" and reify it, hence emptying it of its true voice in our circumstances. A broken home is a place where speech and speaking have died, or at least where a certain understanding of speech and speaking have failed. "We can no longer speak to each other. (S)he no longer understands me. We no longer meet each other's needs," says the wife of her husband, and the husband of his wife. So they decide to "split," hoping and looking for another with whom a true speaking can be established and in which the "relationship" can be "meaningful."

What is most striking in all of this is how impossible it is to break a home. Just as we have said there can be no separation of human living from language, so we say there can be no such thing as a broken home. Language and speaking, in the sense that they are that which grant an abode for the being of mortals, are endless, as the poets say, and as we witness in all our talk. It is impossible for human beings to "break" language and still be human. So too, it is impossible to break a home. That is, even though one may go through all the legal procedures necessary to nullify a marriage and, hence, formally dissolve a home, still, the voice of that home continues to speak for the rest of one's life: indeed, in one way or another, for all eternity through one's progeny.

It is one of the deep agonies of those who go through a divorce, particularly where children are involved, to realize how difficult, if not impossible, it is to really and truly "separate." When, for instance, a separation takes place and things settle down, the wondering begins: "Perhaps we should have tried harder" (For us there is only the trying, the rest is not our business, the poet said.); "Maybe I was unreasonable in my demands"; "Let's try a reconciliation?" In the case where no children are involved, separation is easier; the rupture of language, of living 
together, can be endured or glossed over. But where children are involved, it is impossible. In many societies a marriage is not complete or sealed until children are born. It is a recognition that the birth of a child in a relationship marks the point at which two people, a man and a woman, become irrevocably fused in one flesh through their offspring. So that for us, even when a union is "dissolved" the voice of the union still speaks-through our remorse, or through the new problems created by "blended families," etc.

This ontological understanding of a child as one who makes two one, has been beautifully expressed by Jung in his essay "The Phenomenology of the Child Archetype," where he shows the dominance of the theme of child as reconciler in early Greek mythology. We might also note its centrality in the Christian story of the Incarnation, where God embodies himself first as a child, in an event which gathers around a rude crêche of shepherds, politicians, and rulers from the East. It is children who gather us together as teachers in schools, as educators in universities, at conferences or as authors in journals. Why else would we be here? But it is also a mark of our time that in the midst of an inordinate spoken interest concerning children, it is not really children in which we are interested. That is, as is the case with almost everything we "touch" in an empirical objectivist, positivistic tradition such as ours, the deeds of our lives, including our language, have been reified to such a degree that we have lost the art of hearing the deep messages and calls uttered in the very midst of our doing. The reification of language, that condition of our own making from which we must now pray for deliverance, reduces all our doing and all our speaking to a form of power negotiation which stifles and suffocates us all. If we are to live at all, to speak at all, we must learn how to give it up and to let the voice of language itself speak through us. Such a giving up, such a losing, is also a finding, a coming home to the abode where we mortals may dwell again. Living in language, in the power of language itself to shape us and mould us, is the only true living: a way of speaking, which is a breathing with the poets, a form of singing. It is a response to a different call. "Real singing is a different breath," said the poet Rilke; "A breath for nothing. A wafting in the god. A wind." So should our pedagogy be-a different breath, a breath for nothing. Then will our life together with our young be just that, a living and a dwelling together as mortals in the house of being.

\section{Notes}

1. This article was presented at the annual conference of the American Educational Research Association in New York, New York, April, 1981.

\section{References}

Eliot, T. S. Four Quartets (1944). London: Faber and Faber, 1979.

Erny, Pierre, Childhood and Cosmos, New York: New Perspectives Press, 1971.

Heidegger, M. Poetry, Language, Thought (1971). Translated by Albert Hofstadter, New York: Harper Colophon Books, 1975. 
Hopper, Stanley Romaine, and David R. Miller, editors. Interpretation: The Poetry of Meaning, New York: Harcourt, Brace and World, Inc., 1967.

Jung, C. F. "The Phenomenology of the Child Archetype." In C. G. Jung Jung and C. Kerenyi, editors. Essays on a Science of Mythology, New Jersey: Princeton University Press, 1969.

Rilke, R.M. Sonnets to Orpheus 1, 3. Translated by M. D. Herter Norton, New York: W. W. Norton, 1942. 